\title{
Can Laughter Lead to Learning?: Humor as a Pedagogical Tool
}

\author{
Faieza Chowdhury ${ }^{1}$ \\ ${ }^{1}$ Southeast University, Banani, Dhaka 1213, Bangladesh \\ Correspondence: Faieza Chowdhury, Southeast University, Dhaka 1213, Bangladesh.
}

Received: July 7, 2021

Accepted: August 25, 2021

Online Published: September 1, 2021

doi:10.5430/ijhe.v11n1p175

URL: https://doi.org/10.5430/ijhe.v11n1p175

\begin{abstract}
The word humor can be defined as something which is perceived to be funny, comical, or amusing. However, in the case of humor perception plays a key role. This is mainly because what is regarded as humorous by one person may not be funny to another person. Hence, humor like beauty lies in the eyes (ears) of the beholder. The potential of humor as a pedagogical tool is not a new concept in education. Teachers around the world have a mixed attitude towards the use of humor in the classroom as a pedagogical tool. Thus, in this study we sought to investigate the perceptions of students towards the use of humor as a teaching tool at higher education institutions in Bangladesh. For this purpose, we have performed both quantitative and qualitative analysis. In the quantitative part of the study, we collected data from 300 students and performed a binary logistic regression. On the other hand, for the qualitative analysis we have undertaken interviews of 30 selected students at a higher academic institution in Bangladesh. Overall, the results of this study indicate that most of the students considered humor as a positive and beneficial teaching tool in the classroom.
\end{abstract}

Keywords: humor, student learning, pedagogical tool, tertiary level, Bangladesh

\section{Introduction}

As the higher education dynamics have changed rapidly in the last few years, it is vital for the teachers to reexamine their pedagogical strategies to create a sense of community within higher educational settings. Lecturing in the class can be ineffective at times as it is difficult for the instructors to hold students' attention for a long time. Unfortunately, many students often view most of their classes as boring and difficult. Dullness in the class can kill students' attention and interest in any subject. Through effective teaching, educators need to turn negative perceptions of students into positive outcomes. Educators need to be creative as they play a critical role to create an environment that is optimal for learning. Humor has been identified as one of the teaching techniques which can create a positive classroom environment. When a teacher successfully creates a supportive learning environment, the students in the class are more likely to be receptive to learning. Hence transmitting knowledge to the students by using strategies such as storytelling or jokes can generate interest in the learning process. Humor is one of the most essential traits of a good teacher (Horng et al., 2005). An instructor who does not have a humorous nature can still incorporate humor in the class by using cartoons, comics, or funny video clips (Weimer, 2013). Teaching is a form of show-biz and teachers need to act as performers in the classroom. When we talk about education the word 'humor' is often not mentioned in the same context, but findings from studies of several researchers suggest that the use of humor in educational settings, can lead to positive students' learning in the class (Garner, 2006; Banas et al., 2011; James, 2004; Kheer et al., 1999). According to Miller (1979), instructors need to develop a deep sense of humor. Similarly, Lowman (1994) pointed out that a teacher is a performer and a motivator. According to Richmond et al. (2015), factors that can predict students' views of a teacher's effectiveness in the class includes student-teacher rapport, student engagement, and perceived humor of the teacher. Walker (2008) conducted a 15 years longitudinal study where he asked students to respond to what qualities of the most memorable teacher encouraged them to learn. His findings indicate that students emphasize the personal traits of teachers rather than academic qualifications. Walker concluded that memorable teachers share 12 important attributes of which having a good sense of humor was one of those traits. Humor creates a relaxing and friendly environment for the students, helps students to make better connections with teachers and peers in the classroom, and contributes to a more enjoyable learning environment. Despite the positive effects of using humor in the class, feedback from the students suggest that most teachers do not consider humor as a formal pedagogical tool. 
The use of humor during the lecturing process requires a proper balance between systematically engaging in humor and irrelevant comedy (Baid \& Lambert, 2010). Teachers engaging in irrelevant comedy in the classroom can lead to students being falsely satisfied with little to no academic benefits. Moreover, excessive use of humor during teaching can lead to students getting distracted from the subject matter (Lei et al., 2010). Moreover, a teacher acting as a performer is not a universally shared perception across higher education institutions. According to Atherton (2002), entertainment should be an epiphenomenon or a spin-off from the achievement of learning, not a routine to it. One problem with using humor in teaching is the fact that some students may develop the belief that learning is easy (Olson \& Clough, 2003). Berk (1998) states that there are three main reasons why many educators at higher education institutions are reluctant to use humor in the class. Firstly, since humor is not part of any formal curriculum, secondly, there are misconceptions that to use humor a person needs the skills of a comedian and third is a wide common belief among many educators that teaching is a serious profession and usage of humor in teaching can be undignified and frivolous. This study is significant as it provides useful information to educators and policymakers in Bangladesh to examine the subject of classroom humor. Moreover, we conducted both qualitative and quantitative analysis to generate useful data on the effectiveness of applying humor in the class from the students' perspective.

This paper clears some professional myths about the use of humor in higher educational settings. We highlighted some of the benefits and drawbacks of using humor as a pedagogical tool in the class. Discussed different forms of humor which educators can incorporate into their classroom. In addition, we presented our findings from both quantitative and qualitative analysis on the effectiveness of applying humor in the classroom from the perspectives of students. The main purpose of this study was to determine the perceptions and experiences of the students in Bangladesh towards the use of humor in higher education as a pedagogical tool to foster effective teaching. The significance of this study lies in the fact that this is probably the first study in Bangladesh that attempts to assess the effectiveness of humor in the classroom as a pedagogical tool. To our best knowledge, there are no other prior studies conducted earlier in Bangladesh to explore this aspect in the educational setting.

\section{Literature Review}

A lot has been written regarding the positive role of humor in the classroom. It can assist students to retain study materials more effectively (Garner, 2006), reduce classroom anxiety (Lems, 2011; Shibinski \& Martin, 2010), and bring higher evaluation scores for the teachers (Skinner, 2010). Aylor and Opplinger (2003) state that a high humor orientation can reduce psychological distance both inside and outside the classroom. Previous studies affirm that students who perceived their teachers as humorous were more willing to communicate with those teachers. Moreover, students are more willing to discuss personal concerns with a humorous instructor leading to a more meaningful teacher-student interpersonal relationship. Wanzer et al. (2010) state that the use of humor in the classroom can have positive effects on students leading to greater motivation on the part of the students to process course materials in more effective ways. Baid \& Lambert (2010) states that by putting students at ease, humor can bridge the gap between students and teachers. There are some positive influences of using humor in the classroom including creating a positive academic climate, alleviating students' anxiety, and enhancing students' motivation to learn (Banas et al., 2011). Ziv (1988) conducted a study on 161 students and his findings indicate that those groups of students who experienced humor in the class achieved higher scores in the final examination compared to other groups. Garner (2006) divided 117 students into two groups and both the group of students was shown a digital recording in the class. However, while one group saw a digital recording in a humorous version style, the other group of students saw the same recording in a more conventional style. Findings indicate that students who saw the humorous version of the recording were able to recall and retain more information in comparison to the control group. Other previous studies suggested that according to students, teachers who use humor in the classroom are more likable, boost their morale, increases class attentiveness, and facilitates learning more effectively (Torok et al., 2004). A survey conducted by Deiter (2000) revealed that students prefer teachers who do have a sense of humor over teachers who either do not have any humor or do not show it in the class. Students in this study stated that the use of humor is not a waste of classroom time as often perceived by most educators. Students do not expect teachers to behave like clowns or comedians however they do want educators to teach the class materials in a more entertaining manner. Norrick (1993) pointed out that a so-called sense of humor can be counted as a virtue in society. This quality is often considered a desirable leadership trait. According to Hill (1988), "if teachers can teach a student to have a sense of humor about the very serious things in life, they are teaching much more than facts and figures". Hackathorn et al. (2011) revealed that students provided positive feedback about teachers who used humor in the class. Moreover, these students also showed higher success rates and greater levels of engagement in the class. 
There is a shared belief among educators and students that learning should be a fun process (Shatz \& LoSchiavo, 2006). Humor can promote learning by enhancing students' attention and interest in the class. According to Shatz and Coil (2008), humor allows teachers to capture and maintain students' attention while teaching them difficult topics and course content. Ivy (2013) states that humor reduces stress and anxiety. Additionally, it can also stimulate brain activity and increase creativity. James (2004) states that one of the most important characteristics of the best and most effective teachers is humor. Eskey (2010) found that humor makes teachers more approachable to the students. Anderson (2011) found in his study that humor increases group cohesion and connectivity. Micari and Pazos (2012) reported that students' perception of which class is hard or which specific class is easy was based on their rapport with the course instructor. Humor helps to build a positive connection between students and teachers.

\subsection{Benefits of Humor as a Pedagogical Tool}

Previous researchers affirmed that there are many benefits of using humor in the classroom as it can contribute to a relaxing and friendly classroom environment, increasing students' interest, creating stronger bonds with peers, and making the learning process more entertaining (Senior, 2001; Medgyes, 2001; Schmitz, 2002). Ravichand (2013) reveals that the use of humor in the class can reduce students' tension and boredom while arousing their interest in learning. Munoz (2005) states that the use of humor can contribute to developing students' visual memory. Morrison (2008) highlights some key benefits of the use of humor such as it maximizes students' brainpower, enhances their creativity, facilitates communication, creates an optimal learning environment, supports the change process, and contributes to healthy mind/body balance. Humor helps to create a positive class environment where students feel secure and comfortable hence they are more inclined to interact with their classmates and teachers (Poirier \& Wilhelm, 2014; Ocon, 2015; Aboudan, 2009). Several researchers have found that incorporating humor into the classroom maximizes instructional effectiveness (Deiter, 2000; Wanzer, 2002). Humor can also enhance students' learning in the class and their motivation to learn (McCroskey et al., 2006). Some previous studies also revealed that the use of humor in the classroom can improve students' language skills. Researchers have found that humor improves students' speaking abilities (Sunani, 2012; Syafiq \& Saleh, 2012), writing ability (Latiff \& Daud, 2013), grammatical ability (Salehi \& Hesabi, 2014), listening ability (Rafiee et al., 2010). Moreover, some researchers also found that using humor can help to develop students' comprehension ability and enhance the retention of learning materials (Munoz, 2005; Ziyaeemehr et al., 2011; Medgyes, 2002). Nevertheless, there are some studies where it was pointed out that humor does not always lead to the enhancement of learning (Houser et al., 2007).

The use of humor as a pedagogical tool in the field of education also provides various psychological and physiological benefits. According to Berk (1998), some of the psychological positive effects of humor include enhanced self-esteem, increased self-motivation, and reduced anxiety. Moreover, some of the physiological benefits of humor are improved respiration, stimulated circulation, and enhanced muscle relaxation. Despite the above many benefits of humor, the main reason for an educator for using humor in the classroom is to enhance students' learning. The application of humor in the classroom can create a positive learning environment by breaking down communication barriers between students and teachers (Hill, 1988). Hill states that when teachers are not afraid to use the sense of humor in the class, students tend to relax and become better listeners. Students feel less inhibited about asking questions from teachers. Humor creates a strong rapport between teachers and students. A teacher who makes mistake and is willing to laugh at himself-herself gives a clear signal to the students that the teacher is like any other human. This creates a friendly class environment as students will be more willing to learn from their teachers without any potential fear of getting ridiculed. Humor enables students to retain subject matter especially if the humor reinforces the class materials (Hill, 1988).

The use of humor allows teachers to gain students' attention and keep their interest in the material being taught in the class. Some previous studies affirmed that students are more likely to attend classes where the instructor uses humor and more likely to skip boring classes. Hence humor can create a positive, entertaining, and fun class environment that promotes class attendance and students' learning. Berk (1998) reported some other benefits of humor which include increased cognitive retention, reduced negativism and hostility in the classroom, improved students' attitude towards the course and instructor. Finally, from the teachers' perspective, the use of humor in the class allows teachers to teach students in a more fun and enjoyable manner. Nevertheless, to use humor effectively, teachers need to use their creativity regarding how to incorporate humor within the course content.

\subsection{Drawbacks of Humor as a Pedagogical Tool}

Although most previous studies highlighted the potential benefits of using the humor in the classroom, some researchers also reported its shortcomings. Baid and Lambert (2010) state that inappropriate usage of humor by teachers can decline students' self-esteem and create a hostile classroom environment. Moreover, humor can have 
negative impacts on some students in the class due to cultural differences. Nasiri \& Mafakheri (2015) pointed out that teachers should be careful regarding the consequences of humor across cultural lines. Overall, the previous findings in literature while somewhat sporadic and quite often anecdotal are decidedly favorable towards the usage of humor as a pedagogical tool in the classroom.

\subsection{Definition of Humor}

Although humor is an abstract concept and there is no single agreed definition to it, but some attempts were made by previous researchers to classify humor utilized by instructors in the classroom. Faulkner (2011) states that humor is any form of physical activity or spoken statement intentionally or otherwise that causes others to react by smiling, giggling, etc. Leung (2004) defines humor as "the ability to understand, enjoy and express what is amusing". Wanzer et al. (2006) state that humor can be defined as "anything that the teacher and/or students find funny or amusing". According to Berk (1998), humor can be defined as "kindly contemplation of the incongruities of life and the artistic expression thereof".

\subsection{Classification of Humor}

There is a common myth that one must be a comedian to be able to use humor effectively. However, the use of humor can both benefit and hinder the learning process. Researchers have tried to identify various types and categories of humor. If humor in the class focuses on a student being the joke of the class then such humor is undesirable. However, when an instructor uses humor in the class while taking appropriate measures to prevent any kind of negative effects on the students then such humor can have a positive impact on the students' learning. To become an effective teacher in today's world, educators must use all forms of teaching aids and one of such vital aid is laughter.

In many previous studies, researchers categorized humor into different types. Chee (2003) has classified humor into four main groups: 1. Textual form, 2. Pictorial form, 3. Verbal form, and 4. Action/game form. Shade (1996) also categorized humor into four main sub-categories as 1. Figural humor, 2. Verbal humor, 3. Visual humor and 4. Auditory humor. In his study he further clarified that figural humor includes cartoons and caricatures, verbal humor is things like jokes, parody, riddles, irony while visual humor includes practical jokes, clowning, and impersonation and finally auditory humor can be impressions, noises, and sounds. Ziyaeemehr \& Kumar (2014) have categorized humor into three types as verbal humor, non-verbal humor, and combines humor. Some examples of verbal humor are word plays, riddles, stories, and jokes. Making funny faces and gestures can be examples of non-verbal humor. Finally, some examples of combined humor are monologue, parody and skit. According to Wanzer et al. (2006), class humor can be divided into four main categories: 1 . Humor directly related to the class, 2 . Humor unrelated to the class, 3. Unplanned humor and 4. Self-disparaging humor. Hativa (2001) categorized humor in three ways mainly 1. Verbal such as wordplays and funny stories 2. Non-verbal such as gestures and facial expressions and 3 . Combination of two such as parody and monologue. Berk (1998) further states that any humorous material have three key components: 1. A commonly understood situation, 2. A build-up of suspense or anticipation and 3. An unexpected twist or punch-line.

In general, a common misconception is that humor only includes funny jokes and comics. However, the concept of humor is much wider and includes various types of humor ranging from riddles to puns, word games to theatres. Hence educators need to develop their competence in classroom humor by familiarizing themselves with different forms of humor.

\section{Methodology}

In this paper, we adopted the mixed method approach where both the quantitative and qualitative techniques were employed to explore the effectiveness of humor as a pedagogical tool in Bangladesh. For this purpose, we conducted a survey utilizing the questionnaire as an instrument. For the quantitative research, a close-ended questionnaire was designed and utilized as an instrument. In the survey, 300 undergraduate students were asked to fill out a self-administered questionnaire send to them via email. All the respondents in this study attended at least one course of study where the instructor was funny and applied humor in the classroom. Additionally, we also conducted a structured open-ended interview on 30 selected students in which the participants were asked 5 open-ended questions. Hence in this study, we followed the hybrid approach where both quantitative and qualitative analysis was performed.

This part of the research is divided into five sub-sections: 1. Sampling technique 2. Data collection 3. Validity and Reliability of data and instruments 4. Data analyses and 5. Regression model. 


\subsection{Sampling Technique}

In this study, the total population consisted of 1500 students in a Business School at a private university in Bangladesh of which 300 students were selected as the final sample size by applying the simple random sampling technique (SRS). At a 95\% confidence level, 5\% confidence interval from the total population of 1500 students, a sample size of 300 was selected (surveysystem.com). On the other hand, for the qualitative part of the study, we selected 30 students using the convenience sampling technique. According to Burns (1999), interviews are a popular and widely used means of collecting qualitative data. Flick (2006) states that the purpose of an interview "is to reveal existing knowledge in a way that can be expressed in the form of answers and so become accessible to interpretation". In this study, we have conducted a structured open-ended interview where the questions of the interview were predetermined in a fixed orderly fashion. The participants for the personal interview were selected based on accessibility and familiarity.

\subsection{Data Collection}

To collect the primary data we applied the survey technique and utilized the questionnaire as an instrument. The perceptions of the students regard to the application of humor in the classroom for enhancement of learning were analyzed. Additionally, in the qualitative part of the study, we recorded the responses of 30 undergraduate students on 5 open-ended questions. All feedback from the participants was evaluated, classified, and analyzed. Moreover, we also collected data from secondary sources such as academic journals, books, articles, magazines, university data banks, government archives, etc. To triangulate the data, we obtained information through different procedures to heighten the dependability and trustworthiness of the data. Generally, before and after collecting data, a researcher also needs to consider the validity and reliability of the data.

\subsection{Validity and Reliability of Data and Instrument}

According to Burns (1999), validity is an essential criterion for evaluating the quality and acceptability of research. Fraenkel \& Wallen (2003) states that the quality of the instruments utilized in a study will conclude the research based on information using those instruments. Thus, the data and instrument of the study need to be validated. Internal validity is concerned with the congruence of the research findings with reality (Creswell, 2014). To boost the internal validity of the research data and instruments, we applied the following methods recommended by Merriam (1998): member checks and peer examination. We implemented the member checking method by conducting a follow-up interview with the participants of the study and allowing them to provide feedback on the findings of the study. We also adopted the peer debriefing strategy where an expert other than the main researcher(s) reviewed the findings of the study. The plausibility of data analysis and interpretation by peers can augment the validity of the research.

Nunan (1999) states that reliability deals with consistency, dependability and replicability of the results obtained from a piece of research. In quantitative research, obtaining similar results may be possible as the data are in numerical form but in the case of qualitative research where the information collected is more subjective, getting the same results can be more difficult (Mohammad, 2013). Thus, Lincoln \& Guba (1985) point out that rather than obtaining similar results, the focus should be on obtaining dependability and consistency. Lincoln \& Guba (1985) and Merriam (1998), suggested that to ensure the dependability of the results three techniques may be employed: investigators' position, triangulation, and audit trial. In thus study, we adopted the first two techniques.

\subsection{Data Analysis}

In this paper, we intend to explore the opinions of students on the usage of humor in the class as a pedagogical tool. To achieve this goal we conducted both quantitative and qualitative research. Firstly, we collected primary data through a survey technique utilizing a structured questionnaire as an instrument. To explore the students' opinions of the effectiveness of using humor in the class, we performed the binary logistic regression. Students were asked to provide their opinions on 20 close-ended questions on a Five-point Likert scale with five possible responses: strongly agree (SA), agree (A), neutral (N), disagree (DA) and strongly disagree (SDA). Moreover, a regression model was developed and the primary data collected from the survey was analyzed using the STATA statistical software.

\subsection{Regression Mode}

The main purpose of this study was to determine the perceptions of students within an academic institution in Bangladesh towards the use of humor as a pedagogical tool to foster effective learning. For this purpose, the binary logistic technique was applied. The Binary Logistic Regression is an appropriate technique to apply when the dependent variable is dichotomous (Mahmud et al., 2014). In this study, the dependent variable "enhancement in students' learning" can have two possible outcomes "application of humor in the classroom leads to greater students' 
learning" which was coded as 1 or another outcome "application of humor in the classroom does not lead to improvement in students' learning" which was coded as 0 .

\section{The model can be specified as:}

$\mathrm{Pi} /[1-\mathrm{Pi}]=\alpha+\beta_{1} \mathrm{X}_{1}+\beta_{2} \mathrm{X}_{2}+\beta_{3} \mathrm{X}_{3}+\beta_{4} \mathrm{X}_{4}+\beta_{5} \mathrm{X}_{5}+\beta_{6} \mathrm{X}_{6}+\mu$

\section{where:}

\section{Dependent Variables:}

$\mathrm{Pi}=$ probability that students' learning enhances due to application of humor in the class.

[1-Pi] = probability that students' learning will not be enhanced due to application of humor in the class.

\section{Independent Variables:}

$\mathrm{X}_{1}=$ use of verbal humor such as jokes in the class;

$\mathrm{X}_{2}=$ use of visual humor such as cartoons and videos;

$\mathrm{X}_{3}=$ use of audio humor such as audio clippings;

$\mathrm{X}_{4}=$ use of body language such as making funny faces and gestures ;

$\mathrm{X}_{5}=$ use of fun games and puzzles;

$\mathrm{X}_{6}=$ use of self-effacing humor such as making funny personal remarks;

$\alpha=$ is the constant for the equation;

$\beta=$ coefficient of the independent variable; and

$\mu=$ is the error term for the equation.

\section{Findings and Discussion}

\subsection{Findings from Quantitative Research}

In Table 1, we can see the results from the binary logistic regression. In this model, the dependent variable is dichotomous thus it can have two possible outcomes: "probability that students" learning enhances due to application of humor in the class" and "probability that students' learning will not be enhanced due to the application of humor in the class". This was assessed by using six key indicators: use of verbal humor such as jokes in the class $\left(\mathrm{X}_{1}\right)$, use of visual humor such as cartoons in the class $\left(\mathrm{X}_{2}\right)$, use of audio humor such as audio clippings $\left(\mathrm{X}_{3}\right)$, use of funny body language by the course instructor $\left(\mathrm{X}_{4}\right)$, use of fun games and puzzles in the class $\left(\mathrm{X}_{5}\right)$ and use of self-effacing humor $\left(\mathrm{X}_{6}\right)$. It is expected that these six different categories of humor applied in the classroom by the teacher as a pedagogical tool will enhance students' learning. The findings indicate that verbal humor and funny body language; these two variables have positive and significant relations to the dependent variable 'students' learning'. Thus it is an indication that students' learning will increase as the teachers make their classes fun and more entertaining by using jokes and funny body language. The other three independent variables; visual humor, audio humor, and fun games are also positively related to the dependent variable though the results are not statistically significant. Moreover, one specific independent variable 'self-effacing humor' is negatively related to the dependent variable. This indicates that self-effacing humor is not very effective in fostering students' learning in the class. We have calculated the probability of the coefficients using the odd ratios from the binary logistic regression. The probability that verbal humor will lead to enhancement in students' learning is $88 \%$. Furthermore, fun body language and fun games have probabilities of $89 \%$ and $59 \%$, respectively. Thus, in both cases there is more than $50 \%$ chance that the application of these two humor techniques in the classroom will enhance students' learning. Moreover, the probability of greater learning in the class due to visual humor and audio humor is $50 \%$ and $48 \%$, respectively. Overall, the findings from the binary logistic regression indicate that most of the independent variables of humor do have a positive impact on the dependent variable 'students' learning'. 
Table 1. Results of Binary Logistic Regression

\begin{tabular}{|c|c|c|c|c|}
\hline Variables & Coefficient & Level of Significance & Odd Ratio & Probability \\
\hline Verbal humor & 1.998 & 0.025 & 7.381 & $88 \%$ \\
\hline Visual humor & 0.003 & 0.996 & 0.997 & $50 \%$ \\
\hline Audio humor & 0.091 & 0.861 & 0.913 & $48 \%$ \\
\hline Fun body language & 2.084 & 0.045 & 8.043 & $89 \%$ \\
\hline Fun games and puzzles & 0.352 & 0.290 & 1.422 & $59 \%$ \\
\hline Self-effacing humor & -0.069 & 0.743 & 0.933 & $48 \%$ \\
\hline \multicolumn{5}{|c|}{ Pseudo $\mathrm{R}^{2}=0.5328$} \\
\hline \multicolumn{5}{|c|}{ Note: Probability $=[$ Odd $/(1+$ Odd $)]$} \\
\hline
\end{tabular}

\subsection{Findings from Qualitative Research}

In the qualitative study, a researcher seeks believability based on coherence, insight, and instrumental utility (Eisner, 1991), and trustworthiness (Lincoln \& Guba, 1985) through a process of verification. The main focus of a qualitative study is on the participants' participation and experiences (Locke et al., 1987). Due to the COVID-19 pandemic, it was not possible to conduct a face-to-face personal interview thus the questions were asked from the participants via the telephone. For qualitative analysis, we selected 30 undergraduate students at a private university in Bangladesh and asked them 5 open-ended questions regarding the usage of humor in the classroom (Appendix A). All the responses of the participants were recorded, categorized, summarized, and later analyzed for interpretation. The feedback of the participants was labeled in different categories and a coding process was adopted. The intent of this coding is to identify repetitive themes and coherent responses of the participants.

Firstly we asked the participants, which quality of the teacher influences their decision when making choices about class enrolment. $93 \%$ of the students stated that they want their teachers to be friendly, while $5 \%$ mentioned that they want their teacher to be entertaining or funny in some way and the remaining $2 \%$ highlighted the gender preference issues. In response to the second question, the majority of the students gave a positive affirmation that they like teachers who apply humor in the class. Some of these students shared positive experiences of learning in a class where humor was applied such as Response 1: "I appreciate humor in teachers as it makes learning enjoyable"; Response 2: "I prefer to take courses with teachers who are funny as I can easily share my problems without feeling scared". Response 3: "Personally I connect better with teachers who are easy going and fun". Nevertheless, some students pointed out their negative experiences in the class such as Response 4: "My teacher made fun of my poor marks in the class which was embarrassing for me". Response 5: "My teacher sometimes made jokes about my English accent which I did not like". In response to the fourth question, all the participants stated that they would prefer to enroll in a class where the teacher is more fun than serious as it will later assist them to easily build a friendly connection with the teacher. Finally, in response to the last question where we asked students about their thoughts on using humor in the class as a pedagogical tool to enhance learning, $95 \%$ of the students affirmed that humor can make learning more interesting and the remaining 5\% stated that they do not have any idea about this matter.

\section{Conclusion}

In this paper, we explored the learners' perception of studying in a class where the course instructor applied humor as a pedagogical tool. The findings of this study indicate that verbal humor such as jokes, visual humor such as cartoons, audio humor such as audio clippings, funny body language, and fun games applied in the class as a teaching tool can have a positive impact on students' learning. However, the usage of humor in the classroom must be non-offensive. Humor which is used to put down the self-esteem of any individual, group, race, religion and, nationality should be avoided. Shibinski \& Martin (2010) pointed out that teachers should refrain from engaging in humor that can adversely impact the classroom environment. This is supported in our research findings as self-effacing humor was found to have a negative impact on the students' learning. Moreover, findings from qualitative research also indicate that most of the students preferred to attend classes where the teachers are funny and less serious. 
However, like any other study, this research has some limitations. The study was conducted on a sample size of 300 students from a single academic institution in Bangladesh. Thus in the future, further research can be carried out in this area of study by collecting samples from different academic institutions covering wider geographic, demographic, and socioeconomic dimensions so that the findings can be generalized. Although many prior studies in the context of developed countries are available in the literature, addressing how humor can be applied in the classroom to enhance students' learning (Mc Croskey et al., 2006; Deiter, 2000; Wanzer, 2000), this is probably the first study in Bangladesh, where the usage of humor as a pedagogical tool was analyzed in a higher education institution. Furthermore, this study also has some practical implications. Most of the teachers in Bangladesh consider teaching as a serious profession and the application of humor in the classroom is often deemed as inappropriate. However, the findings of this research will enable educators to think differently and to comprehend how humor can be effectively utilized in the classroom as a pedagogical tool to enhance students' learning.

\section{References}

Aboudan, R. (2009). Laugh and learn: Humor and learning a second language. International Journal of Arts and Sciences, 3(3), 90-99.

Anderson, D. (2011). Taking the "distance" out of distance education: A humorous approach to online learning. MERLOT Journal of Online Learning and Teaching, 7(1). Retrieved from http://jolt.merlot.org/vol7no1/anderson_0311.htm.

Atherton, J. (2002). Heterodoxy: Against a positive learning environment. Retrieved from http://www.doceo.co.uk/heterodoxy/positive

Aylor, B., \& Opplinger, P. (2003). Out-of-class communication and student perceptions of instructor humor orientation and socio-communicative style. Communication Education, 52, 122-134. https://doi.org/10.1080/03634520302469

Baid, H., \& Lambert, N. (2010). Enjoyable Learning: The role of humor, games, and fun activities in nursing and midwifery education. Nurse Education Today, 30, 548-552. https://doi.org/10.1016/j.nedt.2009.11.007

Banas, J. A., Dunbar, N., Rodriguez, D., \& Liu, S. (2011). A review of humor in education settings: Four decades of research. Communication Education, 60, 115-144. https://doi.org/10.1080/03634523.2010.496867

Berk, R. A. (1998). Professors are From Mars, Students are From Snickers. Madison, WI: Mendota Press.

Berk, R. A. (1996). Student ratings of ten strategies for using humor in college teaching. Journal on Excellence in College Teaching, 7(3), 71-92.

Burns, A. (1999). Collaborative action research for English language teachers. Cambridge: CUP.

Chee, A. W. S. (2003). Humor in TEYL- reducing classroom anxiety. Retrieved from the World Wide Web: http://www.teyl.org/article2.html.

Creswell, J. W. (2014). Research Design: Qualitative, Quantitative and Mixed Methods Approaches. Thousand Oaks, California, USA. SAGE Publications.

Deiter, R. (2000). The use of humor as a tool in the college classroom. NACTE Journal, 44, 2028

Eisner, E. W. (1991). The enlightened eye: Qualitative inquiry and the enhancement of educational practice. New York, NY: Macmillan.

Eskey, M. (2010). Humor in online classrooms: New ways to learn and laugh. Faculty Focus. Retrieved from http://www.facultyfocus.com/articles/online-education/humor-in-onlineclassrooms-new-ways-to-learn-and-laug $\mathrm{h} /$

Faulkner, T. O. (2011). Is humor a useful classroom tool to motivate and help young Korean learners to remember? Unpublished Master's Thesis, Birmingham, England.

Flick, U. (2006). An introduction to qualitative research. London: Sage.

Fraenkel, J. R., \& Wallen, N. E. (2003). How to design and evaluate research in education. Fifth ed. New York: McGraw-Hill.

Garner, R. L. (2006). Humor in pedagogy. How ha-ha can lead to aha! College Teaching, 54(1), 177-180. https://doi.org/10.3200/CTCH.54.1.177-180 
Hackathorn, J., Garczynski, A. M., Blankmeyer, K., Tennial, R. D., \& Solomon, E. D. (2011). All kidding aside: Humor increases learning at knowledge and comprehension levels. Journal of The Scholarship of Teaching and Learning, 11(4), 116-123.

Hativa, N. (2001). Teaching for Effective Learning in Higher Education. Netherlands: Kluwer Academic Publishers. https://doi.org/10.1007/978-94-010-0902-7

Hill, D. J. (1988). Humor in the Classroom: A Handbook for Teachings (and Other Entertainers!). Springfield, IL: Charles C. Thomas.

Horng, J. S., Hong, J. C., ChanLin, L. J., Chang, S. H., \& Chu, H. C. (2005). Creative teachers and creative teaching strategies. International Journal of Consumer Studies, 29, 352-358. https://doi.org/10.1111/j.1470-6431.2005.00445.x

Houser, M. L., Cowan, R. L., \& West, D. A. (2007). Investigating a new education frontier: Instructor communication behavior in CD-ROM texts-do traditionally positive behaviors translate into this new environment? Communication Quarterly, 55, 19-38. https://doi.org/10.1080/01463370600998319

Ivy, L. L. (2013). Using humor in the classroom. Education Digest, 79(2), 54-57.

James, D. (2004). A need for humor in online courses. College Teaching, 52(3), 93-94. https://doi.org/10.3200/CTCH.52.3.93-120

Kheer, N., Molstad, S., \& Donahue, R. (1999). Using humor in the college classroom to enhance teaching-effectiveness in dread courses. College Student Journal, 33(3), 400-406.

Latiff, A. A., \& Daud, N. M. (2013). Pre-service ESL teachers' perceptions of parody integration in digital stories. World Applied Sciences Journal, 21, 28-35.

Leung, B. (2004). Development of an objective humor appreciation measure (HAM). Paper presented at AARE 2004 International Education Research Conference, The University of Melbourne, Victoria, Australia.

Lei, S. A., Cohen, J. L., \& Russler, K. M. (2010). Humor on learning in the college classroom: Evaluating benefits and drawbacks from instructors' perspectives. Journal of Instructional Psychology, 37(4), 326-331.

Lems, K. (2011). Pun work helps English learners get the joke. The Reading Teacher, 65(3), 197-202. https://doi.org/10.1002/TRTR.01027

Lincoln, Y. S., \& Guba, E. G. (1985). Naturalistic inquiry. Beverly Hills, CA: Sage. https://doi.org/10.1016/0147-1767(85)90062-8

Lowman, J. (1994). Professors as performers and motivators. College Teaching, 42, $137-141$. https://doi.org/10.1080/87567555.1994.9926844

Mahmud, T., Hassan, K., Alam, F., Sohag, K., \& Rafiq, F. (2014). Opinion of the zakat recipients on their food security: A case study on Bangladesh. International Journal of Islamic and Middle Eastern Finance and Management, 7(3), 333-345. https://doi.org/10.1108/IMEFM-08-2012-0079

McCroskey, J. C., Richmond, V. P., \& Bennett, V. E. (2006). The relationships of student end-of-class motivation with teacher communication behaviors and instructional outcomes. Communication Education, 55(4), $403-414$. https://doi.org/10.1080/03634520600702562

Medgyes, P. (2001). How's this for fun? The role of humor in the ELT classroom and ELT teaching materials. In Reflections on language and language learning: in honor of Arthur van Essen (pp. 105-18). Philadelphia, PA: John Benjamins. https://doi.org/10.1075/z.109.14med

Medgyes, P. (2002). Laughing Matters: Humor in the language classroom. Cambridge: Cambridge University Press.

Merriam, S. B. (1998). Qualitative research and case study applications in education. San Francisco: Jossey-Bass.

Miller, D. (1979). College teaching: The highest form of show biz. Community College Frontiers, 8(1), 10-13.

Micari, M., \& Pazos, P. (2012). Connecting to the professor: Impact of the student-faculty relationship in a highly challenging course. College Teaching, 60(2), 41-47. https://doi.org/10.1080/87567555.2011.627576

Mohammad, Z. (2013). Mixed Method Research: Instruments, Validity, Reliability and Reporting Findings. Theory \& Practice in Language Studies, 3(2), 254-262. https://doi.org/10.4304/tpls.3.2.254-262

Morrison, M. K. (2008). Using humor to maximize learning: The link between positive emotions and education. Maryland: Roman and Littlefield Education. 
Munoz, B. J. (2005). Learning through humor: using humorous resources in the teaching of foreign languages. The A.T.I.S Bulletin, 42-46.

Nasiri, F., \& Mafakheri, F. (2015). Higher education lecturing and humor: From perspectives to strategies. Higher Education Studies, 5(5), 26-31. https://doi.org/10.5539/hes.v5n5p26

Norrick. N. R. (1993). Conversational Joking. Indianapolis: Indiana University Press.

Nunan, D. (1999). Research methods in language learning. Eighth printing. Cambridge: CUP.

Ocon, R. (2015). Using humor to create a positive learning environment. Retrieved from: https://www.asee.org/public/conferences/56/.

Olson, J., \& Clough, M. (2003). Computer-assisted education can undermine serious study. In J. Torr (Ed.), Computers and education (pp. 56-65). Farmington Hills, MI: Greenhaven Press.

Poirier, T. I., \& Wilhelm, M. (2014). Use of Humor to Enhance Learning: Bull's Eye or Off the Mark. American Journal of Pharmaceutical Education, 78(2), 27. https://doi.org/10.5688/ajpe78227

Rafiee, M., Kassaian, Z., \& Dastjerdi, H. (2010). The application of humorous songs in EFL classrooms and its effects on listening comprehension. English Language Teaching, 3(4), 100-108. https://doi.org/10.5539/elt.v3n4p100

Ravichand, M. (2013). Humor: An aid to learning and instruction. Journal of Humanities and Social Science, 11(1), 18-21. https://doi.org/10.9790/0837-1111821

Richmond, A., Berglund, M., Epelbaum, V., \& Klein, E. (2015). Teaching of Psychology, 42(2), 119-125. https://doi.org/10.1177/0098628315569924

Salehi, F., \& Hesabi, A. (2014). Impact of teaching grammar through humor on Iranian EFL learners. Theory and Practice in Language Studies, 4(8), 1641-1652. https://doi.org/10.4304/tpls.4.8.1641-1652

Schmitz, J. R. (2002). Humor as a pedagogical tool in foreign language and translation courses. Humor: International Journal of Humor Research, 15(1), 89-113. https://doi.org/10.1515/humr.2002.007

Senior, R. (2001). The role of humor in the development and maintenance of class cohesion. Prospect, 16(2), 45-54.

Shade, A. R. (1996). License to laugh: Humor in the classroom. Connecticut: Greenwood Publishing.

Shatz, M., \& Coil, S. (2008). Regional campus teaching ain't a joke but humor can make it effective. Association for University Regional Campuses of Ohio, 14, 105-117.

Shatz, M., \& LoSchiavo, F. (2006). Bringing life to online instruction with humor. Radical Pedagogy, 8(2). Retrieved from http:// www.radicalpedagogy.org/radicalpedagogy/Bringing_Life_to_Online_Instruction_with_Humor.html

Shibinski, K., \& Martin, M. (2010). The role of humor in enhancing the classroom. Athletic Therapy Today, 15(5), 27-29. https://doi.org/10.1123/att.15.5.27

Skinner, M. E. (2010). All joking aside: Five reasons to use humor in the classroom. Education Digest, 76(2), 19-21.

Sunani, W. (2012). The effect of using humor strategy toward speaking ability of the second year students at SMPN 2 singing district kuantan singing regency. Unpublished Bachelor's Degree Graduation Thesis. Faculty of Education and Teacher Training of State Islamic University of Sultan.

Syafiq, A., \& Saleh, M. (2012). Humorous English teaching material for improving students' speaking skill with high and low learning motivation. Language Circle: Journal of Language and Literature, 7, 45-54.

Torok, S. E., McMorris, R. F., \& Lin, W. C. (2004). Is humor an appreciated teaching tool? Perceptions of professors' teaching styles and use of humor. College Teaching, 52, 14-20. https://doi.org/10.3200/CTCH.52.1.14-20

Walker, R. J. (2008). Twelve characteristics of an effective teacher: A longitudinal, qualitative, quasi-research study on in-service and pre-service teachers' opinions. Educational Horizons, 87(1), 61-68.

Wanzer, M. B., Frymier, A. B., \& Irwin, J. (2010). An explanation of the relationship between instructor humor and student learning: Instructional humor processing theory. Communication Education, 59, 1-18. https://doi.org/10.1080/03634520903367238 
Wanzer, M. B., Frymier, A. B., Wojtaszczyk, A. M., \& Smith, T. (2006). Appropriate and inappropriate uses of humor by teachers. Communication Education, 55(2), 178-196. https://doi.org/10.1080/03634520600566132

Weimer, M. (2013). Humor in the classroom: Forty years of research. Retrieved from http://www.facultyfocus.com/articles/effective-teaching-strategies/humor-in-the classroom-40-years-of-research

Ziyaeemehr, A., \& Kumar, V. (2014). The relationship between instructor humor orientation and students' report on second language learning. International Journal of Instruction, 7(1), 91-106.

Ziyaeemehr, A., Kumar, V., \& Abdullah, M. (2011). Use and non-use of humor in academic ESL classrooms. English Language Teaching, 4(3), 111-119. https://doi.org/10.5539/elt.v4n3p111 


\section{Appendix A}

\section{Questions for Qualitative Research}

- Which quality of a teacher is most important to you when making choices about class enrolment?

- What are your thoughts about teachers using humor in the class as part of the teaching process?

- Did you attend any classes where the teacher used humor and how would you describe your experience?

- If you get a choice to make a selection between two faculties one serious and another fun, which class would you prefer to enroll and why?

- What are your thoughts about teachers using humor in the class to enhance students' learning?

\section{Copyrights}

Copyright for this article is retained by the author(s), with first publication rights granted to the journal.

This is an open-access article distributed under the terms and conditions of the Creative Commons Attribution license (http://creativecommons.org/licenses/by/4.0/). 